\title{
Analisa Usability Pengguna Website Tokopedia Menggunakan Metode McCall
}

\author{
Aleksander Agung Reformasi, Iklima Ermis Ismail \\ Program Studi Teknik Informatika Jurusan Teknik Informatika dan Komputer \\ Politeknik Negeri Jakarta \\ alexanderlionheart298@gmail.com; iklimaermis.ismail@tik.pnj.ac.id
}

Diterima: 10 September 2019. Disetujui: 1 November 2019. Dipublikasikan : 29 November 2019

\begin{abstract}
Abstrak - Dengan semakin berkembangnya E-commerce di Indonesia setiap tahunnya, belanja online menjadi kebiasaan bagi sebagian orang. Dengan segala kemudahan yang diberikan, banyak orang beranggapan bahwa belanja online adalah salah satu sarana untuk mencari barangbarang yang dibutuhkan. Tokopedia merupakan salah satu E-commerce terbesar di Indonesia dengan banyak pengguna. Penelitian ini dilakukan untuk menganalisis usability pada website Tokopedia dengan pendekatan metode McCall. Instrumen penelitian menggunakan kuesioner dengan 50 responden dalam pengumpulan data. Kuesioner berisi 13 pernyataan untuk mengukur aspek efektivitas, efisiensi dan kepuasan dalam penggunaan website Tokopedia. Kuesioner disebar secara random. Hasil dari analisis menunjukkan bahwa keseluruhan atribut usability mendapatkan nilai diatas 70\% (rata-rata diatas nilai 3). Dapat disimpulkan bahwa website Tokopedia telah memiliki nilai aspek usability yang baik.
\end{abstract}

Kata Kunci: belanja online; e-commerce; website; tokopedia; kuesioner; usability

\section{PENDAHULUAN}

Saat ini perkembangan teknologi informasi sangat kompleks dan memberi banyak dampak bagi kehidupan manusia, termasuk dunia bisnis dalam internet yang disebut E-Commerce, yaitu suatu cara berbelanja atau berdagang secara online yang memanfaatkan internet di mana terdapat website yang menyediakan get dan delivery. Di Indonesia terdapat beberapa toko online, antara lain Tokopedia, Shopee, Bukalapak, Lazada, Blibli, dan lain-lain. Berdasarkan data yang dikutip dari situs www.inet.detik.com, Tokopedia meraih peringkat pertama sebagai toko online yang paling banyak dikunjungi di Indonesia dengan total pengunjung sebanyak 1,2 miliar pada tahun 2019 [1].

Aspek kualitas perangkat lunak merupakan salah satu hal yang penting dalam pengembangan suatu software [2]. Suatu perangkat lunak bukan hanya dilihat dari hasil produknya tapi juga dilihat dari sisi tahap pengembangan perangkat lunak itu sendiri [3].

Penelitian ini mencoba menganalisis website Tokopedia dengan analisa usability menggunakan metode McCall yang berisi 11 faktor pendukung keberhasilan kualitas suatu perangkat lunak terhadap kepuasan kebutuhan pengguna, yaitu correctness, reliability, efficiency, integrity, usability, maintainability, flexibility, testability, portability, reusability, dan interoperability [4]. Faktor-faktor tersebut dibagi menjadi 3 kelompok utama, yaitu: Product Transition, Product Revision dan Product Operation. Usability masuk ke dalam kategori Product Operation [5].

Usability adalah suatu ukuran, dimana pengguna dapat mengoperasikan dan menggunakan perangkat lunak tanpa memerlukan banyak latihan [4]. Pengukuran usability ditentukan oleh dua faktor, yaitu: Operability dan Training. Operability merupakan kecocokan operasi penggunaan sistem oleh end-user. Training merupakan tingkatan dimana software dapat digunakan oleh user baru. Penilaian ini dapat diperoleh melalui analisis kuesioner hasil observasi end-user [5].

Selain McCall, untuk pengukuran usability juga terdapat metode Cognitive Walkthrough. Namun metode ini lebih fokus pada pengukuran kesesuaian antara desain antarmuka dengan proses bisnis yang dimiliki aplikasi[6].

Metode McCall telah banyak digunakan untuk mengukur usability aplikasi pada berbagai bidang. Mulyanto (2016) juga menggunakan McCall untuk mengukur kualitas Sistem Informasi Akademik pada suatu universitas meliputi desain, spesifikasi dan koding dan memperoleh hasil yang baik sebesar $72,68 \%$ [7]. Penelitian yang dilakukan oleh Hidayati, dkk. pada tahun 2017, menggunakan metode McCall pada sistem Informasi Akademik (SIAK) suatu politeknik, memperoleh hasil faktor usability sudah dapat memenuhi kebutuhan pengguna sebesar $65,3 \%$ [8]. Penelitian yang dilakukan oleh Arif, dkk. juga 
menggunakan metode McCall untuk mengukur usability sistem bonus pada suatu perusahaan dengan hasil sebesar $74,72 \%$ yang menunjukkan usability sistem bonus pada perusahaan tersebut sudah baik [9].

Penelitian ini bertujuan menganalisa usability untuk pengukur tingkatan, dimana suatu produk bisa digunakan oleh pengguna tertentu untuk mencapai tujuannya dengan lebih efektif, efisien, dan memuaskan pengguna web aplikasi Tokopedia. Penelitian ini bersifat deskriptif kualitatif dengan menggunakan kerangka kerja McCall. Instrumen penelitian berupa kuesioner sebagai cara untuk pengumpulan data yang nantinya akan dianalisis menggunakan standar kualitas McCall.

\section{METODE PENELITIAN}

Metode penelitian yang digunakan pada penelitian ini ditampilkan pada Gambar 1.

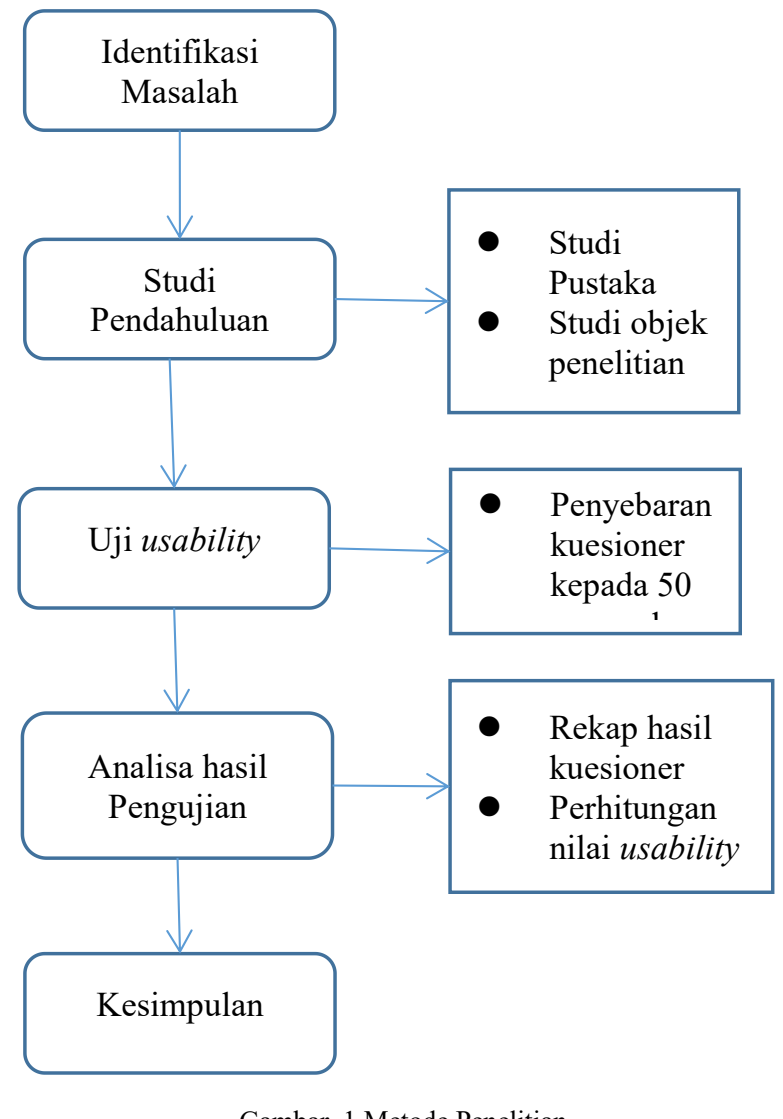

\section{A. Objek Penelitian}

Objek penelitian ini adalah website Tokopedia yang akan dianalisis usability-nya dengan cara menyebarkan kuesioner. Jumlah responden yang dijadikan sampel sebanyak 50 orang yang ditentukan secara random dari kuesioner yang disebar secara acak.

\section{B. Pengumpulan Data}

Instrumen penelitian yang digunakan berupa kuesioner yang terdiri dari 13 komponen pernyataan yang mewakili kelima aspek usability yaitu learnability, eficiency, memorability, errors, dan satisfaction [10]. Setiap pernyataan dari kuesioner dinilai menggunakan skala likert yang merupakan skala psikometrik yang paling banyak digunakan dalam riset berupa survei [11]. Terdapat lima pilihan skala dengan format yaitu: $1=$ Sangat Kurang Setuju (SKS), 2 = Kurang Setuju (KS), $3=\operatorname{Netral~(N),~} 4=$ Setuju(S), 5 = Sangat Setuju (SS).

Pengumpulan data dilakukan dengan menyebarkan kuesioner secara acak menggunakan media Google Form. Pengguna mengisi kuesioner yang sudah dibagikan berdasarkan pengalamannya (apa saja yang dilihat dan dirasakan) pada saat menggunakan website Tokopedia.

\section{Analisa Data}

Pengolahan data ini meliputi semua aspek dari analisa usability metode McCall. Analisa dilakukan pada setiap faktor untuk menentukan hasil dan mencari kesimpulan apakah website ini sudah memenuhi standar kualitas yang baik menurut metode McCall.

\section{HASIL DAN PEMBAHASAN}

Berdasarkan hasil penyebaran kuesioner secara random kepada responden, data hasil kuesioner kemudian dianalisa menggunakan model skala likert. Terdapat 5 persamaan yang digunakan dalam perhitungan Skala Likert setiap pernyataan kuesioner.

\section{A. Menghitung Total Skor Responden Setiap} Pernyataan

Perhitungan ini dilakukan dengan menggunakan persamaan (1) :

$$
\text { TxPn }
$$

dimana

$\mathrm{T}=$ Total jumlah responden yang memilih Pn $=$ Pilihan angka skor Likert

\section{B. Interpretasi Skor Perhitungan}

Untuk memperoleh hasil interpretasi, terlebih dahulu harus diketahui skor tertinggi (Y) dan skor terendah $(\mathrm{X})$ untuk item penilaian dengan persamaan (2) dan (3):

$Y=$ skor tertinggi likert $x$ jumlah responden
$X=$ skor terendah likert $x$ jumlah responden

Berdasarkan data responden diperoleh hasil yaitu :

- Jumlah skor tertinggi untuk item "SANGAT SETUJU" adalah 5 x $50=250$, 
- Jumlah skor terendah untuk item "SANGAT KURANG SETUJU" adalah 1 x $50=50$.

- Jika total skor yang didapat dari responden yaitu 213, maka penilaian interpretasi responden terhadap website Tokopedia tersebut adalah nilai yang dihasilkan dengan menggunakan persamaan Index \% (4).

Index $\%=$ Total Skor $/ Y * 100$

Pada Tabel I ditampilkan kriteria interpretasi skornya berdasarkan interval.

TABEL I. PERSENTASE NILAI

\begin{tabular}{|c|l|c|}
\hline \multicolumn{1}{|c|}{ Jawaban } & \multicolumn{1}{|c|}{ Keterangan } & Angka \\
\hline $0 \%-19.99 \%$ & $\begin{array}{l}\text { Sangat Kurang } \\
\text { Setuju }\end{array}$ & 1 \\
\hline $20 \%-39.99 \%$ & Kurang Setuju & 2 \\
\hline $40 \%-59.99 \%$ & Netral & 3 \\
\hline $60 \%-79.99 \%$ & Setuju & 4 \\
\hline $80 \%-100 \%$ & Sangat Setuju & 5 \\
\hline
\end{tabular}

\section{Penyelesaian Akhir}

Penyelesaian akhir dihitung dengan menggunakan persamaan (5).

Persentase Nilai $=$ Total skor $/$ Y $\times 100$

Pernyataan 1: Website Tokopedia mudah untuk dioperasikan saat anda melakukan transaksi online. Dengan menggunakan persamaan (1), diperoleh:

- Responden yang menjawab SS = 21 x 5=105

- Responden yang menjawab $\mathrm{S}=22 \times 4=88$

- Responden yang menjawab $\mathrm{N}=6 \times 3=18$

- Responden yang menjawab KS $=1 \times 2=2$

- Responden yang menjawab SKS $=0 \times 1=0$

- Total skor $=213$

Penyelesaian akhir dihitung dengan menggunakan persamaan (5), diperoleh :

Persentase Nilai $=(213 / 250) \times 100=85,2 \%$

Pernyataan 2: Website Tokopedia memiliki tampilan yang menarik dan mudah dipahami

Dengan menggunakan persamaan (1), diperoleh:

- Responden yang menjawab SS $=10 \times 5=50$

- Responden yang menjawab $S=31 \times 4=124$

- Responden yang menjawab $\mathrm{N}=7 \times 3=21$

- Responden yang menjawab KS $=2 \times 2=4$

- Responden yang menjawab SKS $=0$ × $1=0$

- Total skor $=199$

Penyelesaian Akhir dihitung dengan menggunakan persamaan (5), diperoleh :

Persentase Nilai $=(199 / 250) \times 100=79,6 \%$

Pernyataan 3: Website Tokopedia memiliki sistem yang aman, sehingga dapat meyakinkan bagi anda untuk melakukan transaksi belanja online dengan menggunakan persamaan (1), diperoleh:

- Responden yang menjawab SS $=16 \times 5=80$
- Responden yang menjawab $S=21 \times 4=84$

- Responden yang menjawab $\mathrm{N}=12 \times 3=36$

- Responden yang menjawab KS $=1 \times 2=2$

- Responden yang menjawab SKS $=0 \times 1=0$

- Total skor $=158$

Penyelesaian akhir dihitung dengan menggunakan persamaan (5), diperoleh:

Persentase Nilai $=(158 / 250) \times 100=63,2 \%$

Pernyataan 4: Secara keseluruhan, saya puas dengan kemudahan penggunaan website Tokopedia Dengan menggunakan persamaan (1), diperoleh:

- Responden yang menjawab SS $=14 \times 5=70$

- Responden yang menjawab $\mathrm{S}=22 \times 4=88$

- Responden yang menjawab $\mathrm{N}=13 \times 3=39$

- Responden yang menjawab KS $=1 \times 2=2$

- Responden yang menjawab SKS $=0 \times 1=0$

- Total skor $=199$

Penyelesaian akhir dihitung dengan menggunakan persamaan (5), diperoleh:

Persentase Nilai $=(199 / 250) \times 100=79,6 \%$

Pernyataan 5: Website Tokopedia cepat dalam menangani masalah, seperti saat web sulit diakses karena terlalu banyak pengunjung yang mengakses secara bersamaan

Dengan menggunakan persamaan (1), diperoleh:

- Responden yang menjawab SS $=7 \times 5=35$

- Responden yang menjawab $S=16 \times 4=64$

- Responden yang menjawab $\mathrm{N}=22 \times 3=66$

- Responden yang menjawab $\mathrm{KS}=5 \times 2=10$

- Responden yang menjawab SKS $=0 \times 1=0$

- Total skor $=175$

Penyelesaian akhir dihitung dengan menggunakan persamaan (5), diperoleh:

Persentase Nilai $=(175 / 250) \times 100=70 \%$

Pernyataan 6: Anda Merasa Mudah dalam bernavigasi dalam website untuk mencari barang yang anda butuhkan

Dengan menggunakan persamaan (1), diperoleh:

- Responden yang menjawab SS $=10 \times 5=50$

- Responden yang menjawab $\mathrm{S}=22 \times 4=88$

- Responden yang menjawab $\mathrm{N}=16 \times 3=48$

- Responden yang menjawab KS $=2 \times 2=4$

- Responden yang menjawab SKS $=0 \times 1=0$

- Total skor $=190$

Penyelesaian akhir dihitung dengan menggunakan persamaan (5), diperoleh :

Persentase Nilai $=(190 / 250) \times 100=76 \%$

Pernyataan 7: Tampilan pada menu website pada Tokopedia mudah untuk dikenali

Dengan menggunakan persamaan (1), diperoleh:

- Responden yang menjawab SS $=8 \times 5=40$

- Responden yang menjawab $S=27$ x $4=108$ 
- Responden yang menjawab $\mathrm{N}=12 \times 3=36$

- Responden yang menjawab KS $=3 \times 2=6$

- Responden yang menjawab SKS $=0 \times 1=0$

- Total skor $=190$

Penyelesaian akhir dihitung dengan menggunakan persamaan (5), diperoleh:

Persentase Nilai $=(190 / 250) \times 100=70 \%$

Pernyataan 8: Informasi mengenai produk yang tersedia di web Tokopedia mudah untuk dicari Dengan menggunakan persamaan (1), diperoleh:

- Responden yang menjawab SS $=11 \times 5=55$

- Responden yang menjawab $S=27$ x $4=108$

- Responden yang menjawab $\mathrm{N}=10 \times 3=30$

- Responden yang menjawab KS $=2 \times 2=4$

- Responden yang menjawab SKS $=0 \times 1=0$

- Total skor $=197$

Penyelesaian akhir dihitung dengan menggunakan persamaan (5), diperoleh:

Persentase Nilai $=(197 / 250) \times 100=78,8 \%$

Pernyataan 9: Tampilan dan tata letak menu website Tokopedia mudah untuk diingat

Dengan menggunakan persamaan (1), diperoleh:

- Responden yang menjawab SS $=4$ × $5=20$

- Responden yang menjawab $\mathrm{S}=28 \times 4=112$

- Responden yang menjawab $\mathrm{N}=10 \times 3=30$

- Responden yang menjawab KS $=8 \times 2=16$

- Responden yang menjawab SKS $=0 \times 1=0$

- Total skor $=178$

Penyelesaian akhir dihitung dengan menggunakan persamaan (5), diperoleh:

Persentase Nilai $=(178 / 250) \times 100=71,2 \%$

Pernyataan 10: Ketika berinteraksi dengan website, anda merasa service center website Tokopedia membantu dalam menyelesaikan masalah anda Dengan menggunakan persamaan (1), diperoleh:

- Responden yang menjawab SS $=4$ x $5=20$

- Responden yang menjawab $S=19 \times 4=76$

- Responden yang menjawab $\mathrm{N}=25 \times 3=75$

- Responden yang menjawab KS $=2 \times 2=4$

- Responden yang menjawab SKS $=0 \times 1=0$

- Total skor $=175$

Penyelesaian akhir dihitung dengan menggunakan persamaan (5), diperoleh:

Persentase Nilai $=(175 / 250) \times 100=70 \%$

Pernyataan 11: Fungsi atau kegunaan yang ditawarkan oleh web Tokopedia sesuai dengan yang seharusnya

Dengan menggunakan persamaan (1), diperoleh:

- Responden yang menjawab SS $=5 \times 5=25$

- Responden yang menjawab $\mathrm{S}=25 \times 4=100$

- Responden yang menjawab $\mathrm{N}=16 \times 3=48$

- Responden yang menjawab KS $=4 \times 2=8$
- Responden yang menjawab SKS $=0 \times 1=0$

- Total skor $=181$

Penyelesaian akhir dihitung dengan menggunakan persamaan (5), diperoleh:

Persentase Nilai $=(181 / 250) \times 100=72,4 \%$

Pernyataan 12: Transaksi Pembayaran yang tersedia di website Tokopedia mudah untuk diakses dan digunakan

Dengan menggunakan persamaan (1), diperoleh:

- Responden yang menjawab $\mathrm{SS}=9 \times 5=45$

- Responden yang menjawab $S=33 \times 4=132$

- Responden yang menjawab $\mathrm{N}=7 \times 3=21$

- Responden yang menjawab KS $=1 \times 2=2$

- Responden yang menjawab SKS $=0 \times 1=0$

- Total skor $=200$

Penyelesaian akhir dihitung dengan menggunakan persamaan (5), diperoleh:

Persentase Nilai $=(200 / 250) \times 100=80 \%$

Pernyataan 13: Kemanan pembayaran sudah terjamin, jika ada masalah dalam pembelian produk Dengan menggunakan persamaan (1), diperoleh:

- Responden yang menjawab SS $=11 \times 5=55$

- Responden yang menjawab $S=25 \times 4=100$

- Responden yang menjawab $\mathrm{N}=13 \times 3=39$

- Responden yang menjawab KS $=1 \times 2=2$

- Responden yang menjawab SKS $=0 \times 1=0$

- Total skor $=196$

Penyelesaian akhir dihitung dengan menggunakan persamaan (5), diperoleh:

Persentase Nilai $=(196 / 250) \times 100=78,4 \%$.

\section{Analisa usability}

Perhitungan hasil data kuesioner dari 50 responden dirangkum seperti pada Tabel II. Nilai pada kolom Keterangan diperoleh mengacu pada Tabel I.

TABEL II. REKAP NILAI USABILITY

\begin{tabular}{|c|c|c|c|}
\hline Pernyataan ke- & Persentase Nilai & Keterangan & Angka \\
\hline \multicolumn{2}{|c|}{ ASPEK SISTEM (SYSTEM) } & \\
\hline 1 & $85,2 \%$ & SS & 5 \\
\hline 2 & $79,6 \%$ & S & 4 \\
\hline 3 & $63,2 \%$ & S & 4 \\
\hline 4 & $79,6 \%$ & S & 4 \\
\hline 5 & $70 \%$ & S & 4 \\
\hline ASPEK PENGGUNA (USER) & S & 4 \\
\hline 6 & $76 \%$ & S & 4 \\
\hline 7 & $76 \%$ & S & 4 \\
\hline 8 & $78,8 \%$ & S & 4 \\
\hline 9 & $71,2 \%$ & S & 4 \\
\hline ASPEK INTERAKSI (INTERACTION) & S \\
\hline 10 & $70 \%$ & SS & 5 \\
\hline 11 & $72,4 \%$ & S & 4 \\
\hline 12 & $80 \%$ & & \\
\hline 13 & $78,4 \%$ & & \\
\hline
\end{tabular}


Tabel II menunjukan nilai kepuasan/penerimaan user (acceptance) terhadap tiap butir pertanyaan yang diajukan. Dapat dilihat bahwa untuk pernyataan 1: "Fungsionalitas website Tokopedia mudah untuk dioperasikan" memiliki persentase nilai $85,2 \%$, termasuk kategori angka 5 (sudah berada diatas 3 atau diatas nilai tengah) dalam skala likert. Ini dapat diartikan bahwa sistem fungsional website Tokopedia mudah dioperasikan atau digunakan oleh pengguna dalam melakukan transaksi perbelanjaan.

Jika disesuaikan dengan masing-masing aspek usability pada Tabel II, dapat dikatakan bahwa sistem fungsional website Tokopedia telah memiliki nilai usability yaitu, learnability, efficiency, memorability, errors, satisfaction yang sangat baik. Mengacu ada penelitian yang dilakukan oleh Firmansyah, maka nilai hasil usability pada 5 atribut pernyataan pada kuesioner sebagai berikut [12]:

a. Nilai atribut "Kemudahan Interface yang menarik dan mudah dipahami" sebesar $79,6 \%$ yang menunjukkan bahwa website Tokopedia telah memiliki nilai aspek Learnability.

b. Nilai atribut "Kemudahan pengoperasian fungsional website Tokopedia" sebesar $85,2 \%$ yang menunjukkan bahwa website Tokopedia telah memiliki nilai aspek Efficiency.

c. Nilai atribut "Kemudahan mengingat kembali menu dan tampilan pada website Tokopedia" sebesar 76\% menunjukkan bahwa website Tokopedia telah memiliki nilai aspek Memorability.

d. Nilai atribut "Cepat dalam menangani masalah overload" sebesar $70 \%$ dan atribut "Kemudahan dan aman dalam melakukan pembayaran" sebesar $78,4 \%$ membuat website Tokopedia dapat dikatakan telah meminimalisasi aspek Errors.

e. Dan keseluruhan atribut memiliki nilai rata-rata di atas 3, yang menunjukkan jika website Tokopedia ini telah mempunyai aspek Satisfaction yang baik.

\section{KESIMPULAN DAN SARAN}

\section{A. Kesimpulan}

Hasil pengukuran usability menunjukkan bahwa secara keseluruhan atribut memiliki usability yang rata-rata skor atau nilainya diatas $70 \%$ dengan kode angka diatas angka 3, sehingga dapat dikatakan bahwa website Tokopedia yang digunakan oleh user telah memiliki nilai aspek usability dan banyak digunakan oleh orang-orang pada saat ini jika ingin melakukan kegiatan belanja online maupun melakukan kegiatan transaksi lainnya, seperti pembayaran tagihan dan sebagainya, serta fungsi dan fitur serta tampilan website pun mudah dimengerti oleh pengguna yang mengunjungi website tersebut.
Hasil penelitian yang menunjukkan bahwa website Tokopedia telah memiliki aspek usability. Maka diharapkan pengguna dapat memanfaatkan website Tokopedia untuk mempermudah dalam menunjang kegiatan belanja online sehari-hari.

\section{B. Saran}

Adapun saran-saran yang diberikan setelah melakukan penelitian ini, sebagai berikut:

1. Saran untuk penelitian selanjutnya dapat membandingkan dengan metode lain, yaitu ISO atau IEEE agar diperoleh hasil pengukuran yang maksimal.

2. Melakukan upgrade sistem transaksi yang ada agar bisa lebih aman lagi dalam bertransaksi.

\section{REFERENSI}

[1] https://inet.detik.com/business/d-4872404/survei-tokopediadan-shopee-adu-kuat-mendominasi

[2] B. Sugiantoro and M. Mustakim, "Analisa Usabilitas Sistem Deteksi Akses Pornografi Pengguna Internet Menggunakan Metode Mccall' S,' vol. 2, no. 1, 2017.

[3] R. K. Hapsari and M. J. Husen, "Estimasi kualitas perangkat lunak berdasarkan pengukuran kompleksitas menggunakan metrik functions oriented," no. December, 2017.

[4] Galin, Software Quality Assurance From Theory to Implementation, England: Pearson Education Limited, 2004.

[5] Pressman. 2002. Rekayasa Perangkat Lunak endekatan praktis (Buku Satu). Yogyakarta : Andi.

[6] R. Sandhika Galih A. 2013.Pengukuran usability Menggunakan Metode Cognitive Walktrough Pada Sistem Informasi Akademik Universitas. Konferensi Nasional Sistem Informasi - KNSI 2014At: STMIK Bumigora Mataram.

[7] Mulyanto, A. 2016. Pengujian Sistem Informasi Akademik Menggunakan McCall's Software Quality Framework. JISKa Vol. 1, No. 1, MEI, 2016: 47-57.

[8] Hidayati, A., Oktariza, E., Rosmaningsih, F., Lathifah, S.A. 2017. Analisa Kualitas Perangkat Lunak Sistem Informasi Akademik Menggunakan McCall. JURNAL MULTINETICS VOL. 3 NO. 1 MEI 2017: 47-51.

[9] Arif, A.H.,Siregar, M.U.,.2018. A Usage of McCall's Software Quality Analysis on the Bonus System of PT Surya Pratama Alam. JISKa Vol. 3, No. 1, MEI, 2018 : 63 72.

[10] Pudjoatmodjo, B. and Wijaya,R. 2016. Tes Kegunaan ( Usabilty Testing ) Pada Aplikasi Kepegawaian Dengan Menggunakan System Usabilty Scale ( Studi Kasus : Dinas Pertanian Kabupaten Bandung ). Jurnal Semnastekno Media online, Vol.4, No.1, 2016. pp. 6-7.

[11] Lestari,S. 2014. Analisis usability Web ( Studi Kasus Website UMKM Binaan BPPKU Kadin Kota Bandung ). JITTER. Vol. 1, No. 1, 2014, pp. 46-51.

[12] Firmansyah, R. 2018. usability Testing Dengan Use Questionnaire Pada Aplikasi Sipolin Provinsi Jawa Barat, Jurnal Swabumi, Vol. 6, No.1 Maret 2018, 1-7. 